\title{
Prospects and Challenges for Small-Scale Mining Entrepreneurs in South Africa
}

Zandisile Mkubukeli* and Robertson Tengeh

Faculty of Business and Management Sciences, Cape Peninsula, University of Technology, South Africa

\begin{abstract}
Small-scale mining entrepreneurs are confronted with a variety of challenges during both the start-up and growth phase of their businesses not only in South Africa, but all over the world. Therefore, losing prospects available to them. The aim of this paper was to explore prospects and challenges faced by small scale mining entrepreneurs in South Africa (SA). To attain this end, a qualitative research paradigm was instituted for both data collection and analysis. The findings of this study concur with the literature, that there are indeed plenty of prospects available to small scale mining entrepreneurs. However, the most outstanding prospects was free training and funding. Nonetheless, the receptiveness of these prospects is somehow conditional.
\end{abstract}

Keywords: Prospects; Challenges; Small scale mining; Entrepreneurs

\section{JEL Classification}

M00, M1, M10, M130

\section{Introduction and Background}

Unemployment and poverty facts are painful, yet these are some of South Africa's vital statistics that cannot be put aside. According to Statistics South Africa the current unemployment rate is $25.5 \%$ of the workforce, with approximately 10 million people subject to high levels of poverty. On the flipside, it is believed that the mining sector has the potential to mitigate South Africa's unemployment and poverty crisis [1].

In this paper we answered the following questions: what are the prospects for small-scale mining entrepreneurs in SA? What are the challenges facing small-scale mining entrepreneurs in SA? We wanted to know two things. Firstly, what prospects are there for small scale mining entrepreneurs in South Africa that can help small scale miners grow their small scale mining operation? Secondly, what are the impediments preventing the latter in establishing sustainable businesses.

Traditionally, the efficacy of small scale mining has been gauged from different perspectives, for instance, Hilson and McQuilken [2] investigated the availability of support structures for small scale mining entrepreneurs and found that, public perception on small scale mining remains consistent, lack of support. Mkubukeli and Tengeh [3] explored the support structures and success factors relevant to smallscale mining and the results of the study and the results affirmed the availability of a comprehensive support structure for aspiring smallscale mining entrepreneurs. Appiah [4] scrutinized the organisation of small scale mining activities and revealed that there are monetary rewards sustained from operating a small scale mine. On the one hand, Dondeyne and Ndunguru [5] investigated small scale mining from a rural developmental perspective; the study found that; mining entrepreneurs fail to fulfil their financial obligations. On the other hand, Childs [6] explored new approaches for governing mining activities and proposed that, small-scale mining to be administered with trading channels for their minerals.

Notwithstanding the prevalence on small scale mining, scholarship on prospects and challenges for small scale mining entrepreneurs in SA is reasonably scanty. Therefore, the research problem under investigation is a remarkably partisan mining sector that favours more established companies, with small scale mining entrepreneurs sidelined. Despite being a significant source of revenue for SA, the current state of the mining sector is one that does not directly benefit previously disadvantaged people. Notwithstanding government interventions, small-scale mining entrepreneurs face numerous challenges during both the business start-up and growth phase of their businesses. This translates to the significant prospects lost. Against the just mentioned backdrop, this paper aimed to: explore prospects and challenges to small-scale mining entrepreneurs in SA.

In view of the foregoing, many would argue that most smallscale mining entrepreneurs lack the capacity to take advantage of the opportunities that are available to them and this is reflected in the sluggish growth of their businesses. On a different note, there is growing evidence that small-scale mining entrepreneurs are growing in numbers and young men and women entrepreneurs are being drawn into small-scale mining all over the world [7]. Despite this seeming contradiction, small-scale mining entrepreneurs, like other entrepreneurs in SA, are confronted by daunting challenges during both the start-up phase and next phases of their businesses.

Given the impediments they face, small-scale mining entrepreneurs are compelled to use rudimentary methods and often conduct smallscale mining operations individually and illegally [8-11]. The use of unorthodox business methods of extracting gold or other mineral resources are deleterious to the environment and human health [1113]. According to Drasch et al. [13] small-scale mining entrepreneurs extract gold from the ore using mercury (a highly toxic chemical), thus creating a gold-amalgamation. Additionally, to separate the gold from the amalgamation, the gold-amalgamation is heated in the open,

*Corresponding author: Mkubukeli Z, PhD candidate and CEO of Zandisile Holdings, Faculty of Business and Management Sciences, Cape Peninsula University of Technology, South Africa, Tel: +27 21959 6417; E-mail: zmkubza@gmail.com

Recieved October 12, 2016; Accepted November 25, 2016; Published November 25, 2016

Citation: Mkubukeli Z, Tengeh R (2016) Prospects and Challenges for SmallScale Mining Entrepreneurs in South Africa. J Entrepren Organiz Manag 5: 202. doi: 10.4172/2169-026X.1000202

Copyright: @ 2016 Mkubukeli Z, et al. This is an open-access article distributed under the terms of the Creative Commons Attribution License, which permits unrestricted use, distribution, and reproduction in any medium, provided the original author and source are credited. 
thus contributing to air pollution. It seems that small- scale mining represents an environmental threat.

Regardless of the challenges small scale mining entrepreneurs face it seems that small scale mining entrepreneurs can exploit a set of prospects. For instance, Anon asserted that mining entrepreneurs in South Africa are likely to exploit the following prospects: direct ownership of mines or either contracting mining services to established mines. Heemskerk and van der Kooye [8] are convinced that given the increased number of prospects for small-scale mining entrepreneurs, small-scale mining entrepreneurs can exploit more of these prospects. In their view this would involve direct ownership of mines, contracting mining services, outsourcing new services and more effective marketing and trading. At present both national and international governments are considering formalising small-scale mining so that the sector can continue to contribute to the development of the rural economy [5]. Some governments have recognised what small-scale mining could offer and are establishing bilateral arrangements. For instance, Mothomogolo [14] acknowledges that Brazil, Russia, India, China and SA (BRICS) have opened up participation in their economies to South African entrepreneurs by means of bilateral agreements.

Despite the significance of small scale mining in rural communities, it seems as if a considerable pool of small scale mining entrepreneurs are limited by capital; geological information and the business know how $[7,8,15,16]$. As a result Mutemeri and Petersen [15] avowed that small scale mining operations are forever inconsistent due to their limitations. Phiri [11] notes that, the limitation of capital and business know how amongst small scale mining entrepreneurs has instead propelled a lack of recognition for the sector. Mutemeri et al. [7] are of the opinion that due to a lack of recognition: small scale mining often consists of informal and illegal activities. Hence, financial institutions are reluctant towards small scale mining.

\section{The Problem Statement}

Traditionally, the efficacy of small scale mining has been gauged from different perspectives, for instance, Hilson and McQuilken [15] investigated the availability of support structures for small scale mining entrepreneurs and found that, public perception on small scale mining remains consistent, lack of support. Mkubukeli and Tengeh [3] explored the support structures and success factors relevant to smallscale mining and the results of the study and the results affirmed the availability of a comprehensive support structure for aspiring smallscale mining entrepreneurs. Appiah [4] scrutinized the organisation of small scale mining activities and revealed that there are monetary rewards sustained from operating a small scale mine. On the one hand, Dondeyne and Ndunguru [5] investigated small scale mining from a rural developmental perspective, the study found that; mining entrepreneurs fail to fulfil their financial obligations. On the other hand, Childs [6] explored new approaches for governing mining activities and proposed that, small-scale mining to be administered with trading channels for their minerals.

Notwithstanding the prevalence on small scale mining, scholarship on prospects and challenges to small scale mining entrepreneurs in SA is reasonably scanty. Therefore, the research problem under investigation is a remarkably partisan mining sector that favours more established companies, with small scale mining entrepreneurs sidelined. Despite being a significant source of revenue for SA, the current state of the mining sector is one that does not directly benefit previously disadvantaged people. Notwithstanding government interventions, small-scale mining entrepreneurs face numerous challenges during both the business start-up and growth phase of their businesses. This translates to the significant prospects lost. Against the just mentioned backdrop, this paper aimed to: explore prospects and challenges to small-scale mining entrepreneurs in SA.

The following section consists of the following: literature survey on small scale mining; prospects and challenges to small scale mining entrepreneurs in SA. Subsequent to that, the research design and strategy will be explained. This is followed with the findings and discussion. Thereafter, the conclusions and limitations are addressed.

\section{Literature Survey}

Although there has been dominate scholarship on small scale mining gauged from different perspectives [3,9-11], limited attention has been paid to the prospects and challenges for small scale mining entrepreneurs. The literature survey is therefore, structured accordingly firstly; an entrepreneur is contextualised. Secondly small scale mining is defined. Thirdly, small scale mining entrepreneurs; and the theoretical framework underpinning this study is presented. Fourthly, prospects and challenges for small scale mining entrepreneurs are discussed. Lastly, a conceptual model is presented as a lens to view the challenges faced by small scale mining entrepreneurs.

\section{Entrepreneur}

According to Bolton and Thompson, an entrepreneur is any person who either creates or innovates a business thus adding value to the consumer. A similar perspective is held by Hisrich et al. asserts that, an entrepreneur is a person that combines resources innovatively in such a manner that new products or services are created in spite of the risk associated thereto. Barringer and Ireland agrees that an entrepreneur assembles the following resources; money, people, business model, the strategy, and transforms these resources into a feasible business startup. Although many would agree that a true definition of entrepreneur is someone who habitually starts a business. However, in the context of this study an entrepreneur is any person that has at least started and operated a small scale mining business, but has not been successful in growing the business to appoint where it is sustainable.

\section{Small-scale mining}

Small-scale mining varies from country to country. Researching this field presents a daunting challenge to researchers throughout the world $[10,11,13,17,18]$. It seems that there is not yet consensus on a single definition of small-scale mining. Phiri [11], for instance, attempts to define small-scale mining by using benchmarking. The determinants he uses are the size of the mine, legality (law abiding or not) of operations, and mining paradigm. Another notable attempt was made by Hentschel et al. [18]. They argue that small-scale mining refers to mining operations with limited mechanisation, conducted by poor individuals or families and young children throughout the world. It can also be said that small-scale mining is defined as a process of mining involving both extracting and commercialising of minerals. However, what the literature neglects to mention is that, small scale miners are not the ones benefiting mostly from the minerals they mine but the syndicate they sell their minerals to. Furthermore, there mere fact that there is not a common understanding of what small scale mining is, may be a mammoth concern policy makers because they do not know what they are dealing with.

This study uses the above definition and confines itself to the prospects and challenges to small-scale mining entrepreneurs; it does not include junior to large scale mining. The following section explores 
the difference between small-scale miners and mining entrepreneurs. It poses the question: Are we dealing with small-scale miners or mining entrepreneurs?

\section{Small-scale mining entrepreneurs}

The evolution of diamond mining in SA saw mine workers making use of shovels and picks as their means of extracting minerals. According to Pegg, small-scale mining entrepreneurs are people driven by poverty to conduct informal and often illegal mining operations. Werthmann contends that small-scale miners are indigenous people in pursuit of financial benefits and social independence. This statement is supported by the views of [19]. Small-scale mining entrepreneurs in Southern Africa employ whoever is available in the host community, thus making it the leading employer in Southern African rural communities [2012]. As a rule, those who start a business are seen as entrepreneurs, regardless of their reasons for starting or running the business. However, in the event of small-scale mining, most small-scale miners are not entrepreneurially orientated, but are poverty driven. Therefore, do not reflect any entrepreneurial characteristics as opposed to large scale mining entrepreneurs.

What most scholars fail to comprehend regarding small scale mining is the fact that there is a clear distinction between a smallscale miner and entrepreneurs in general. This can be illustrated using the work of Nieman and Nieuwenhuizen [20]. Small-scale miners are regarded as survival entrepreneurs; the fact that they operate in isolation and are not educated, means they are not eligible for funding [20]. Although current literature criminalises small scale mining and suggests that small scale miners are illegal miners, the premise has no ground. The reason for that is because small scale miners are more concerned with providing food for their families. Therefore, according to them they are not breaking any law. Hence they are predominately seen as survival entrepreneurs throughout the world. Hence, the challenges they face are inevitable.

It seems as if that scholarship on whether small scale miners are entrepreneurs or not, is by far limited, given that the literature fails to address small scale miners as entrepreneurs rather addresses them as people who are poverty driven and are engaging in small scale mining for the purpose of alleviating poverty.

\section{Theoretical framework underpinning this study}

This section focuses on the push and pull factors of entrepreneurship, these factors are mere reasons behind new venture creation. All things being the same the "pushed" entrepreneurs are more likely to experience challenges therefore losing prospects available to them. This theory is widely utilised to bring to the core factors behind the reason of becoming an entrepreneur. On the one hand, the theory notes that, in most instances, people are forced into entrepreneurship by their circumstance. On the other hand, people can also be enticed to entrepreneurship by opportunities. Nonetheless, in the context of this study, the theory is used to determine whether small scale mining entrepreneurs are pushed or pulled into entrepreneurship, given the correlation between the former, opportunities and challenges.

Push and pull factors of small scale mining entrepreneurs: Currently, there are a number of theories on why people decide to become entrepreneurs. For instance the, the push-pull theories propound that people are pushed into entrepreneurship by their circumstances while others are pulled into entrepreneurship by opportunities [20]. This theory is adopted in this paper to understand the factors that push or entices people to become small-scale mining entrepreneurs.

It is believed that people are often pulled into entrepreneurship by the need for independence or for financial rewards [21]. Shane, Kolvereid and Westhead [22] argue that the vast majority of people are pulled into entrepreneurship by their passion to become entrepreneurs and a need for independence. In similar vein to Shane et al. [22], Barringer and Ireland [17] contend that the factors enticing people into entrepreneurship are the need for independence and pursuit of financial rewards.

In the case of small-scale mining, many consider that smallscale mining entrepreneurs are pushed into entrepreneurship rather than enticed into it, given that small scale miners are people who are pushed into entrepreneurship through poverty, as stated earlier in the argument. The latter view is supported by Kirkwood [23] who contends that most people are pulled into entrepreneurship by their difficult circumstances. This strengthens the call that further exploration is necessary to determine whether small-scale mining entrepreneurs are pushed into entrepreneurship and not pulled into it. Figure 1 illustrates push and pull factors of entrepreneurship in the context of small-scale mining entrepreneurs.

Figure 1 illustrates driving factors towards being an entrepreneur. On the left hand side are the favourable drivers to wards being an entrepreneur and on the right hand side are unfavourable conditions that drives people to become entrepreneurs. Bellow the drivers are explained more in-depth.

Push factors to entrepreneurship: The following are factors that push people to become entrepreneurs. The factors include unemployment, job insecurity, disagreement with management, an inability to fit in with the organisation, or no alternative.

Table 1 illustrates push factors to entrepreneurship. On the left are the factors and on the right is the explanation of the factors. The following table illustrates pull factors to entrepreneurship.

Pull factors to entrepreneurship: There are several factors that

\begin{tabular}{|l|l|}
\hline Push factors to entrepreneurship & \multicolumn{2}{|l|}{ Factors } & Explanation \\
\hline Unemployment & Small scale miners are pushed into small-scale mining by poverty and unemployment [12,18,19,24-27]. \\
\hline Job security & $\begin{array}{l}\text { Small-scale mining entrepreneurs do not seem to have started up their enterprises because they were affected by job } \\
\text { insecurity. The reasons are more likely to be retrenchment, unemployment and employment that is seasonal only, as well as } \\
\text { previous experience as a mine workers. }\end{array}$ \\
\hline Disagreement with management & $\begin{array}{l}\text { It is a fair assumption that few of those in small-scale mining were pushed into entrepreneurial enterprises because of a } \\
\text { disagreement with management. }\end{array}$ \\
\hline Does not fit with the organisation & $\begin{array}{l}\text { Understandably, people's views may often conflict with that of the organisation that employs them. It seems that small-scale } \\
\text { mining entrepreneurs did not leave an organisation to start their own business. They started a small-scale mine to put food on } \\
\text { the table for their family. }\end{array}$ \\
\hline No other alternative & Due to limited alternatives, small-scale mining entrepreneurs may be said to be pushed into entrepreneurship. \\
\hline
\end{tabular}

Table 1: Push factors of entrepreneurship. 


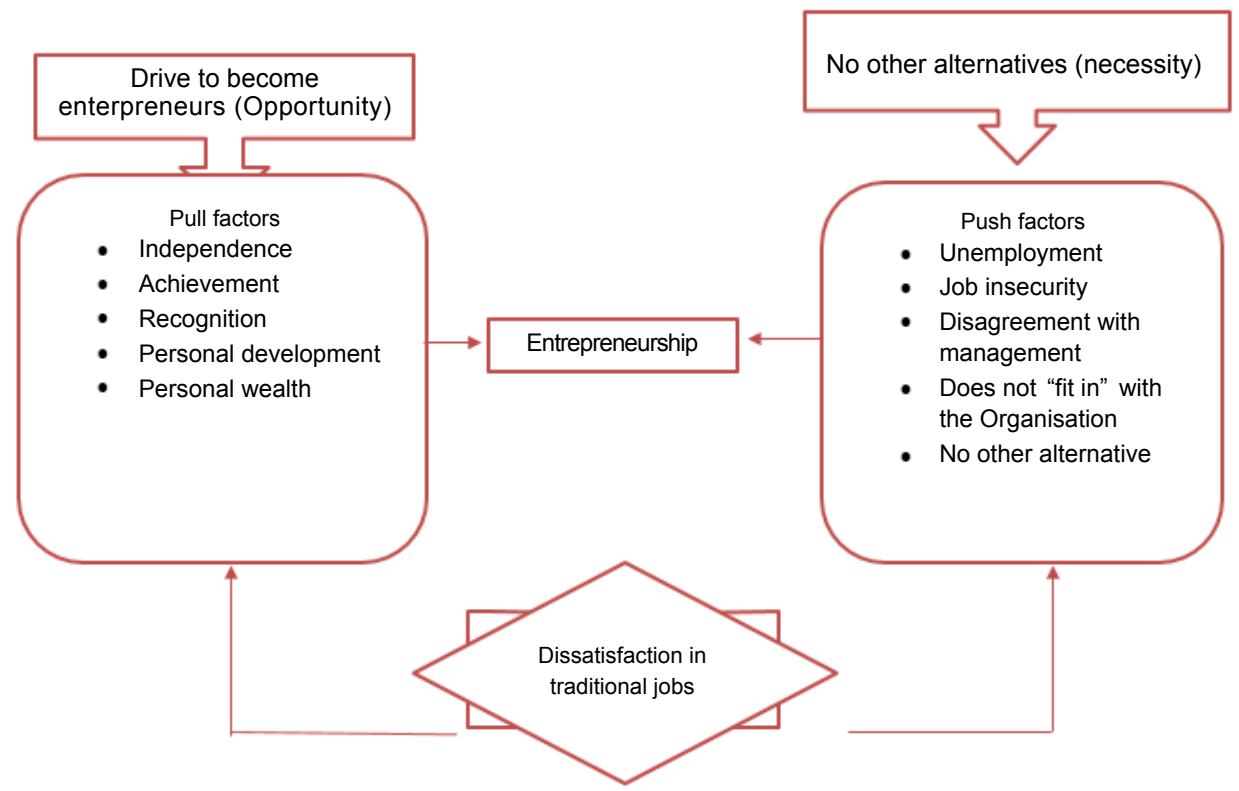

Figure 1: The push and pull factors of entrepreneurship [20].

\begin{tabular}{|c|c|}
\hline \multicolumn{2}{|c|}{ Pull factors to entrepreneurship } \\
\hline Factors & Explanation \\
\hline Independence & $\begin{array}{l}\text { Hentschel et al. [18] point out that small scale mining entrepreneurs are poverty-alleviation. Hence, it is fair to say that small scale mining } \\
\text { entrepreneurs are not pulled into entrepreneurship. }\end{array}$ \\
\hline Achievement & Small-scale miner's main achievement is to put food on the table for their families rather than an establishing entrepreneurial business. \\
\hline Recognition & $\begin{array}{l}\text { Given that there is no evidence that small-scale mining entrepreneurs are driven by a desire for recognition or achievement, many would agree } \\
\text { that small-scale mining entrepreneurs are driven into entrepreneurship. }\end{array}$ \\
\hline Personal development & Small-scale mining entrepreneurs are more likely to exercise their freedom and ability to pursue their own business ideas for financial gain. \\
\hline Personal wealth & $\begin{array}{l}\text { Small scale mining entrepreneurs do not start an enterprise due to pursuit of wealth but rather start businesses to be able to provide food for } \\
\text { their families. }\end{array}$ \\
\hline
\end{tabular}

Table 2: Pull factors of entrepreneurship.

entice people to become entrepreneurs. A few of these are discussed below: independence, achievement, recognition, personal development and personal wealth.

Table 2 illustrates pull factors to entrepreneurship. Factors are located on the left column and on the right column is the explanation of the factors.

The push and pull factor theory highlights the factors that push and entice people to become entrepreneurs. One may thus argue that small scale mining entrepreneurs that are pushed into entrepreneurship are bound to experience more complex challenges than those pulled into entrepreneurship. It seems pulled entrepreneurs are bound to reap the benefits from the prospects available in the mining industry.

\section{Prospects for small scale mining entrepreneurs in SA}

South Africa is one of the countries blessed with considerable mineral resources. Actually many would contend that South Africa is a world leader in mining. The country is renowned for its plethora of mineral resources, accounting for a substantial proportion of world production and reserves, and South African mining companies are essential players in the global industry.

Estimated at R20.3-trillion (\$2.5-trillion), South Africa's total reserves remain some of the world's most valuable and the world's fifth-largest mining sector in terms of GDP value [28]. Despite the
SA's total mineral reserves estimated at \$ 2.5 trillion, the South African mining sector favours most the minority of the country. It is believed that there is considerable potential for the discovery of other worldclass deposits in areas yet to be exhaustively explored. South Africa's prolific mineral reserves include precious metals and minerals, energy minerals, non-ferrous metals and minerals, ferrous minerals, and industrial minerals [28].

Bilateral agreements signed between South Africa and countries, such as Brazil, Russia, India and China (all members of BRICS) open up opportunities for small-scale mining sector entrepreneurs and those in the rural areas in South Africa [14]. Small-scale mining entrepreneurs can create joint ventures with international companies and share synergies in order to increase their business efficiency. Heemskerk and van der Kooye [8] argue that these opportunities mean that small-scale mining entrepreneurs have the prospect of: direct ownership of mines, contracting mining services, outsourcing new services and marketing and trading.

Progressive policy changes in the mining sector in South Africa has created a number of opportunities for small scale mining entrepreneurs. The mining charter is a case in point. The objective of the mining charter includes but not limited to:

- Promoting equitable access to mineral resources

- Expansion opportunities for previously disadvantaged people: 
- Empower previously disadvantaged people

- And to promote beneficiation of SA's mineral resources [29].

Small-scale mining has been documented from different perspectives. For instance Hilson and McQuilken [2] have examined support for small-scale mining entrepreneurs and found that despite small-scale mining being critical to rural economic growth, policy makers' perceptions of this sector have not changed. On the one hand, Appiah's [4] investigated the organisation of small-scale mining activities in Ghana and found that there are financial gains from operating a small-scale mine. On the other hand, Dondeyne and Ndunguru [5], however, take a different view. Their analysis of small-scale mining from a rural developmental perspective found that without government support, small-scale mining entrepreneurs cannot start-up businesses. Drawing from the foregoing, it became imperative to note that small scale mining as a sector is not a priority to policy makers and thus propels a lack of recognition all around the world.

\section{Challenges to small scale mining entrepreneurs in SA}

Challenges facing small scale mining entrepreneurs in South African and those outside SA are no different to one another. However, a common challenge is whether they participate in the economy or not. It is believed that most small scale mining entrepreneurs are operating informally and illegally. In some instances, they tend to operate in abundant mining sites. As a result of this, small scale mining entrepreneurs lack effective participation in the mainstream economy partly due to the wide-ranging challenges they face $[15,16]$. On a different note, Mutemeri, Sellick and Mtegha [7] contend that smallscale mining entrepreneurs are growing in numbers and young men and women entrepreneurs are being drawn into small-scale mining all over the world. Despite this seeming contradiction, small-scale mining entrepreneurs like other entrepreneurs in SA are confronted by daunting challenges during both the start-up phase and next phases of their businesses. Although several studies have confirmed similar challenges, it seems there is quite scantly studies focusing on addressing the various challenges identified as a handicap for small scale miners.
Given the impediments they face, small-scale mining entrepreneurs are compelled to use rudimentary methods and often conduct smallscale mining operations individually and illegally [8-11]. As a direct result of the impediments to small-scale mining entrepreneurs, their use of unorthodox business methods of extracting gold or other minerals are increasingly becoming deleterious to the environment and human health $[12,13]$. Supporting the foregoing premise, Drasch et al. [13], small-scale mining entrepreneurs extract gold from the ore using mercury (a highly toxic chemical), thus creating a gold-amalgamation. Additionally, in order to separate the gold from the amalgamation, the gold-amalgamation is heated in the open, thus contributing to air pollution. Scale-scale mining represents an environmental threat.

\section{Conceptualising the challenges to small-scale mining entrepreneurs in SA}

The problem underpinning this study can be best described using the conceptual model which is based on the literature as a lens to view challenges to and prospects for small-scale mining entrepreneurs in both starting and growing their businesses. Figure 2 is a proposed conceptual model. The model suggests that there are factors (challenges) hindering a small-scale mining business from being sustainable in terms of raising finance and utilising appropriate equipment for business success. The model is categorised into four stages. Colour was therefore, used to distinguish the different stages. The first stage is where small-scale mining entrepreneurs are faced with factors hindering small-scale mining entrepreneurs. The next (second) stage is the Small to Medium Enterprise (SME) business start-up. The third stage is SME growth stage. The fourth (last) stage is the SME sustainability phase. The relationship and meaning of these stages are explained underneath the figure.

The four circles marked with F1, F2, F3 and F4 in the first element of Figure 2, are the challenges that prevent small-scale mining entrepreneurs from establishing successful businesses. These include a lack of geological information, access to markets, and lack of human and financial capital. The start-up, growth and sustainability layers

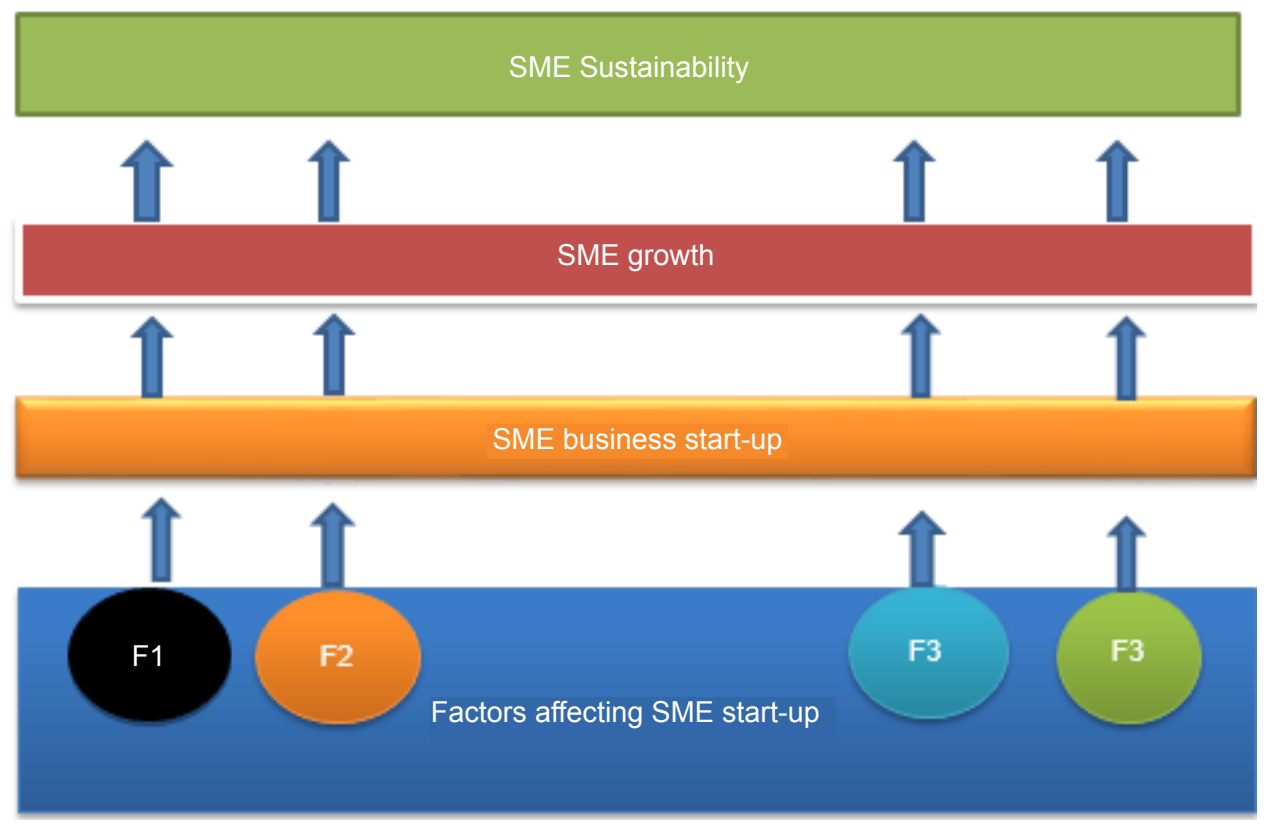

Figure 2: Conceptual model used as the lens to view the research problem. 
of the figure indicate the resources available to small-scale mining entrepreneurs to build sustainable businesses. The relationship between the challenges and start-up, growth and sustainability factors suggests that these businesses would be sustainable if the challenges are mitigated. Furthermore, if each of these phases is successfully achieved, the next phase will follow and the venture will be a successful mining business. However, if the entrepreneurs do not overcome the challenges, the mining business will fail. The trajectory is thus that when those challenges are met, a business start-up will successfully emerge, followed by growth and sustainability. If these challenges are poorly managed, sustainable growth will not be possible. In short, the mining business will not be successful. Therefore, small-scale mining entrepreneurs will have no prospect of building successful businesses (Figure 2).

\section{Research Methodology}

Glaser and Strauss [30] believe that the grounded theory methodology is fated for exploring "grey " areas in order to gain a fresher perspective. Accordingly, the research question in this paper was examined from the grounded theory perspective. This study was conducted in four of the nine provinces of SA. The provinces: included; the Free State; KwaZulu-Natal; Limpopo and Mpumalanga. The prevalence of mining activities laid behind the reason for selecting the aforementioned provinces. Other aspects of the research design and methodology follow.

\section{Research design}

A qualitative research paradigm anchored the methodology of this study, in which face to face interviews were conducted to arrive at an in-depth understanding of this particular phenomenon [31-33].

\section{Research population}

The population of this research constituted of small scale mining entrepreneurs meeting the following requirements: mining entrepreneurs had to be registered with Mintek: mining entrepreneurs had to be in business for more than five years and mining entrepreneurs had to hold a mining permit.

\section{The sampling design}

Owing to the absence of reliable statistics on the status and activities of small scale mining entrepreneurs in South Africa [7], a cohort of mining entrepreneurs was drawn from those registered the database of Mintek. Mintek is a research and development (RandD) organisation that specialises on mineral processing, extractive metallurgy and related technology. The database, provided impetus for the application of random sampling. In support of this approach, Blumberg et al. [34] asserts that sampling can either be done randomly or purposefully. Furthermore, Anderson [35] concurs that in quantitative survey studies, it is important to select probability samples so that statistics can be used to provide generalizations to the population from which the sample was drawn.

In terms of sample size selection, there appears to be no "one size fits all" in qualitative studies. Reports describe single-person studies and yet other commentators suggest sample sizes ranging from to 30 [36]. In all 21, respondents were selected and it was felt that this number of respondents should be able to supply varied and detailed accounts for the purposes of this study. The twenty- one (21) mining entrepreneurs selected for this study were drawn from four provinces, namely: Free State; KZN; Limpopo and Mpumalanga. However, upon confirmation of appointments, it became apparent that ten (10) mining entrepreneurs were no longer in business. Therefore, reducing the sample size to eleven (11) entrepreneurs: Free States compromised of two (2) entrepreneurs: KZN comprised of three (3) entrepreneurs; Limpopo compromised of four (4) entrepreneurs while Mpumalanga had two (2) small scale mining entrepreneurs.

\section{Data collection and analysis}

The data collection approach is anchored to describe the prospects and challenges for small-scale mining entrepreneurs. Therefore, data were collected through face to face interviews with small scale mining entrepreneurs. The mining entrepreneurs were preferred due to the probability of them being in possession of the most comprehensive and accurate information about the activities of the business. Following Weerawardena and Mort [37], open-ended questions, followed by prompts used to elaborate on the discussion and to elicit the views and opinions of the participants were utilized. Each interview lasted for approximately 30 minutes. The interviews were of paramount importance as they helped to validate what the literature postulates regarding small-scale mining. In total, eleven (11) interviews were conducted with small-scale mining entrepreneurs from four different provinces.

The interviews were audio recorded while in progress the researcher also took notes to supplement the audio record. The interviews and observed data were cross checked for consistency and included for further analysis. Content analysis was utilized to categorize the participant's feedback into themes. The transcribed data were then categorized into themes in accordance with the research questions. The emerging themes are reported in-depth in the following section [34].

\section{Findings and Discussions}

In this section the findings and discussion of this research are reported under the verbatim responses and are in phases following the research objectives and emerging themes. In the first phase, the theme question and associated finding are presented in a tabular form. In the second phase, the respondent's answers are presented word verbatim. In the final phase, a summary of the finding relating to the theme question presented and aligned with the literature study.

\section{Prospects for small scale mining entrepreneurs in SA}

In an attempt to establish the prospects small-scale mining entrepreneurs have, a question was formulated to capture such information. The interview findings are tabled below (Table 3).

The table presents prospects for small scale mining entrepreneurs. On the left, the table illustrates the prospects and on the right are the interview findings.

The question that respondents attempted to answer was: what are the prospects available for small-scale mining entrepreneurs in SA? The respondents felt there are numerous opportunities for emerging and small scale entrepreneurs. In particular they highlighted the following themes: growing demand, training, and financial support among others. The verbatim reports highlighting the various themes captured included the following:

\section{What prospects are there for small-scale mining entrepreneurs?}

- Participant 1: "the opportunities for small-scale mining entrepreneurs is that you get training from LIPSA before 


\begin{tabular}{|l|l|}
\hline Theme question: What are the prospects for small-scale mining entrepreneurs in SA? \\
\hline Domain & Interview findings \\
\hline Opportunities & $\begin{array}{l}\text { Forty five per cent (45\%) of small-scale mining entrepreneurs suggested that there were plenty of opportunities for emerging small-scale } \\
\text { mining entrepreneurs. Thirty six per cent }(36 \%) \text { of mining entrepreneurs revealed that there was a huge market for small-scale mining } \\
\text { entrepreneurs, while 9\% regarded the accessibility of mining permits as an opportunity. Furthermore, another 9\% suggested free training } \\
\text { from government as an opportunity for emerging entrepreneurs. }\end{array}$ \\
\hline Exploitation of opportunities + & $\begin{array}{l}\text { Fifty five per cent (55\%) of small-scale mining entrepreneurs noted that, to exploit these opportunities one needed to have funds. Twenty } \\
\text { seven per cent (27\%) of small-scale mining entrepreneurs indicated that to exploit prospects in mining, small-scale mining entrepreneurs } \\
\text { and would-be mining entrepreneurs had to be registered with the relevant authority. On the one hand, } 9 \% \text { of small-scale mining } \\
\text { entrepreneurs revealed that in order for them to exploit these opportunities, companies needed to create joint ventures. On the other } \\
\text { hand, } 9 \% \text { of mining entrepreneurs asserted that government should force big companies to purchase their products. }\end{array}$ \\
\hline Accessibility of opportunities & $\begin{array}{l}\text { Sixty four per cent }(64 \%) \text { of small-scale mining entrepreneurs agreed that it is easy to reap the benefit of the prospects in the mining } \\
\text { industry while 36\% of small-scale mining entrepreneurs claimed that it was very difficult to reap the benefits of prospects in the mining } \\
\text { industry. }\end{array}$ \\
\hline
\end{tabular}

Table 3: Prospects for small scale mining entrepreneurs in SA.

starting a small-scale mine even when you have already started. The training is free of charge"

- Participant 2: "opportunities are there because err, I mean if the market is there it actually means there's a possibility of making good money there you can start small but after sometime then you grow bigger"

- Participant 3: "err the opportunities you get is sometimes the municipality, you find out that they are having projects where the construction needs to lay pavement of which they going to use river sand and sometimes they buy the paving bricks that we are manufacturing and last year we were busy with other they were building a plaza we were the ones who supplied the sand and stones"

- Participant 4: "I think opportunities are there, because in black areas we don't have competition and government is ordering sand from Polokwane instead of Lebowakgomo"

- Participant 5: "There are plenty of opportunities you just need to tap into the mining industry"

- Participant 6: "There are many opportunities ; community development and exposure"

- Participant 7: “There are many opportunities for emerging small-scale mining entrepreneurs. It is easy to get mining permits"

- Participant 8: "There are a lot of opportunities for local people and you need a lot of funds and support and you will create jobs"

- Participant 9: "It's a lot of opportunities, there are a lot of jobs in small-scale mining even local communities are engaging in illegal mining. Small-scale mining provides jobs for rural communities"

- Participant 10: "Opportunities are big, because as we speak everybody wants a structure made of sandstone. People come from as far as Johannesburg to purchase sandstone and we are told that people from Johannesburg export our minerals, so if things can be okay, we will export it ourselves"

- Participant11: "Opportunities are huge, we can work together with small-scale mining entrepreneurs and create partnerships"

Summary of the findings and discussion of the verbatim responses: From a general perspective, the verbatim quotations indicate the opportunities recounted by the respondents come in different forms and are not limited to free training, preferential tenders, and an ever growing demand for mining products.
Aggregating the responses quantitatively, forty five per cent (45\%) of mining entrepreneurs noted that there are plenty of opportunities in small-scale mining. Thirty six per cent $(36 \%)$ of mining entrepreneurs revealed that there is a huge market for small-scale mining. On the one hand, $9 \%$ of small-scale mining entrepreneurs noted that obtaining mining permits for a small-scale mine was an opportunity on its own. On the other hand, $9 \%$ of small-scale mining entrepreneurs mentioned free training and grants as prospects.

Small-scale mining entrepreneurs noted that there are many opportunities for small-scale mining entrepreneurs and would-be entrepreneurs. More importantly, small-scale mining entrepreneurs were the leading employment provider in rural areas across the world $[24,26]$. This statement was supported by the fact that the majority of small-scale mining entrepreneurs in this study agreed that they were the major employer in the rural areas where this study was conducted. This finding is in line with those of Hentschel et al. [18]. Some small-scale mining entrepreneurs had diversified and had built toilets and tennis courts in the community, for instance. There was general agreement that small-scale mining offered many opportunities.

\section{Challenges to small scale mining entrepreneurs}

In this section the findings of the interviews are explored in relation to the themes that were identified:

The table (Table 4) presents challenges facing small scale mining entrepreneurs. On the left, the table illustrates the challenges and on the right are the interview findings.

The objective of the above questions was geared towards answering the main research question. The purpose of this question was to determine the challenges small-scale mining entrepreneurs face in SA. In accordance to theme, this is what the participants had to say;

Given that you currently operate a small-scale mine or you have done so in the past; what are the main financial challenges facing your business?

$>$ Participant 1: "Our main financial challenge is the cost of repairing our equipment, so we end up making a loss"

> Participant 2: Initially, it was start-up capital. That was the most challenging. So we approached government and other private companies and then we formed a partnership.

> Participant 3: Our main financial challenge is that sometimes you find that illegal miners are selling their products at low prices and then people don't buy from us. Even our employees, are stealing our money. 


\begin{tabular}{|c|c|}
\hline \multicolumn{2}{|c|}{ Theme question: What are the challenges facing small-scale mining entrepreneurs in SA? } \\
\hline Domain & Interview finding \\
\hline Financial & $\begin{array}{l}\text { Seventy three }(73 \%) \text { of small-scale mining entrepreneurs agreed that their main financial challenge was the lack of capital and not being able to } \\
\text { purchase the desired equipment for their businesses. Nine per cent }(9 \%) \text { of small-scale mining entrepreneurs said their main financial challenge } \\
\text { was not being able to make profit. Another } 9 \% \text { indicated that not being able to raise capital from financial institutions was a major problem. The } \\
\text { remaining } 9 \% \text { suggested the start-up capital was their major issue as far as finance is concerned. }\end{array}$ \\
\hline Geological & $\begin{array}{l}\text { Ninety per cent }(90 \%) \text { of small-scale mining entrepreneurs asserted that they did not have any challenges as far as geology was concerned while } \\
\text { only } 10 \% \text { indicated that they were either experiencing geological challenges at that point or had experienced them in the past. }\end{array}$ \\
\hline Marketing & $\begin{array}{l}\text { Fifty five per cent }(55 \%) \text { of small-scale mining entrepreneurs said they were not facing any marketing challenges, while } 27 \% \text { indicated that their } \\
\text { main challenge was the lack of an advertising budget. The remaining } 18 \% \text { reported they experienced fierce competition from illegal miners. }\end{array}$ \\
\hline Technical (equipment) & $\begin{array}{l}\text { Only } 9 \% \text { reported that they had no challenges when it came to the technical aspect of their businesses. Seventy three per cent ( } 73 \%) \text { of small- } \\
\text { scale mining entrepreneurs said they did not have access to appropriate equipment. A further } 9 \% \text { of the mining entrepreneurs indicated that their } \\
\text { main challenge was using outdated equipment. The remaining } 9 \% \text { reported that they were using labour intensive equipment. }\end{array}$ \\
\hline Environment & $\begin{array}{l}\text { Twenty seven }(27 \%) \text { of small-scale mining entrepreneurs indicated that they had no environmental challenges. Eighteen per cent (18\%) of } \\
\text { small-scale mining entrepreneurs revealed their challenges revolved around climate issues. Another } 18 \% \text { of small-scale mining entrepreneurs } \\
\text { acknowledged that they were polluting the environment. Yet another } 9 \% \text { of small-scale mining entrepreneurs indicated that their businesses had } \\
\text { labour intensive productions, while the remaining } 9 \% \text { stated that their business faced rehabilitation challenges. }\end{array}$ \\
\hline
\end{tabular}

Table 4: Challenges to small-scale mining entrepreneurs in SA.

$>$ Participant 4: We do get financial challenges, we started very small and even now we can't purchase the equipment that the mine needs. The money the mine makes is very small and you are unable to even fix your equipment.

Participant 5: Lack of finance to purchase equipment for transporting the minerals for beneficiation.

> Participant 6: is that we don't get support from financial institutions; they just don't take us seriously, whether you have a grant or not, you can get top up from financial institutions.

$>$ Participant 7: we sell our minerals at low prices because we don't have proper equipment, so make little money.

$>$ Participant 8: IDC gave me $\mathrm{R} 1$ million to start-up the business, thereafter I have been falling short of money to repay the money.

$>$ Participant 9: Firstly when you starting a business, you need funds and a feasibility study. So I didn't have any funds for conducting a feasibility study so I resigned and took my package.

$>$ Participant 10: We don't have finance to purchase equipment in order for us to cut stones.

$>$ Participant 11: Our main financial challenges are setting up a processing plant and the handling cost of transporting our minerals.

Summary of the Challenges and discussions drawn from the verbatim quotations: Seventy three $(73 \%)$ of small-scale mining entrepreneurs agreed that their main financial challenge was; the lack of finance and not being able to purchase the desired equipment for their businesses. Bradford [38]; Thwala and Phaladi [39]; Ledzani and Netswera [40]; and Mutemeri et al. [7] concur with the above findings. The premise statements are supported by the views held by Cant and Wiid [41]. According to Cant and Wiid [41] the lack of finance (apart from other challenges) facing small businesses in SA is a dominant challenge, therefore, contributing to the failure rate of small-small businesses. On a different note, Van Aardt Smit and Fatoki [42] are of the opinion that the challenges facing small businesses in SA not only limits the start and creation of business but also stagnates the growth of the business. As a result millions of Rands are therefore lost on business ventures due to avoidable mistakes and challenges [43].

Nine per cent $(9 \%)$ of small-scale mining entrepreneurs said their main financial challenge was not being able to make profit. This could be attributable to various elements. However, this study believes that the lack of entrepreneurial flair and managerial competency; financial skills was the crux behind the finding. Small businesses owners in SA lack management skills; financial skills; marketing knowledge [34,38,41,44-46]. According to Fatoki [46] small businesses in SA do not engage in financial planning and control; investment appraisal and financial analysis. Fatoki [45] asserts that challenges facing small business in SA are financially integrated and managerial in nature.

Nine per cent (9\%) indicated that being neglected by financial institutions was a major problem. In supporting this findings, one draws from the work of Ray [47]. According to Ray [47] financial institutions have a set of requirements which are often against applicants that have small-businesses in SA. For instance, In addition, the remaining nine per cent (9\%) suggested the start-up capital was their major issue as far as finance is concerned. As a result of the various challenges of smallscale mining, it is estimated that the failure rate of small businesses in SA is between seventy per cent (70\%) and eighty per cent (80\%) [43].

Due to these hybrid financial challenges, small-scale mining entrepreneurs are not considered viable by financial institutions. Therefore, do not qualify for financial assistance, despite them having grants from government or even personal collateral, which is often rationally low. Therefore, the lack of finance as a predicament for small-scale mining entrepreneurs is perpetuating the struggle of; fulfilling obligations (loan repayments); access start-up capital and conducting feasibility studies.Most importantly, small-scale mining entrepreneurs could not save or perhaps raise money to purchase the desired equipment for their businesses despite being in operation for quite a number of years. As a direct consequence, small-scale mining entrepreneurs could not even raise money for transporting their minerals for beneficiation. In addition to that, small-scale mining entrepreneurs had to sell their minerals below market value due to market imperfections (illegal mining).

Overall, the most outstanding challenge facing small-scale mining entrepreneurs in SA is the lack of finance to purchase appropriate equipment for their respective businesses.

\section{Conclusion}

Although being a significant source of revenue for SA, the current state of the mining sector is one that does not directly benefit the previously disadvantaged. The aim of this study is to investigate the prospects for and challenges to small-scale mining entrepreneurs in 
South Africa. Even though small scale mining entrepreneurs indicated that there are plenty of prospects for them, nonetheless a significant proportion revealed that the receptiveness of these prospects is constraint by the availability of funds. This paper thus demonstrated that the overarching challenge that small scale mining entrepreneurs face is the inadequate finance to purchase the requisite equipment needed for sustainability.

\section{Limitations}

Due to limited resources and time factor, this research was only limited to four provinces of SA, given the spatial distribution of minerals. Additionally, this study investigated prospects for and challenges to small scale mining entrepreneurs. Therefore, this research excluded non mining provinces and Black Economic Empowerment (BEE) mining entrepreneurs.

\section{Recommendations}

To harness challenges of small scale mining entrepreneurs, the supporting agencies of small scale mining entrepreneurs together with the South African government should provide entrepreneurial training prior granting any mining permits to ensure that small scale mining entrepreneurs are entrepreneurially intact prior to engaging in small scale mining. Furthermore, the South African government should ensure that the receptiveness of prospects are not only accessed by those with means to do so rather by every emerging small scale mining entrepreneurs to ensure business success.

- Future research should therefore investigate the complexity behind the receptiveness of the prospects available to small scale mining.

- Future research should also focus on prospects and challenges of BEE mining entrepreneurs.

\section{References}

1. Porter JL (2014) Presidential Address: Are efforts to mechanize SA mines too focused on machinery rather than technology? The Journal of the Southern African Institute of Mining and Metallurgy 114: 681-692.

2. Hilson G McQuicken J (2014) Four decades of support for artisanal and smallscale mining in sub-Saharan Africa: A critical review. The Extractive Industries and Society 1: 104-118

3. Mkubukeli Z, Tengeh RK (2015) Small-scale mining in South Africa: an assessment of the success factors and support structures for entrepreneurs. Environmental Economics 6: 15-24.

4. Appiah $\mathrm{H}$ (1998) Organization of small scale mining activities in Ghana. The South African Institute of Mining and Metallurgy pp: 307-310.

5. Dondeyne S, Ndunguru E (2014) Artisanal gold mining and rural development policies in Mozambique: perspectives for the future. Futures $\mathrm{p}: 1$.

6. Childs J (2014) A new means of government artisanal and small-scale mining? Fairtrade gold and development in Tanzania. Resources Policy 40: 128-136.

7. Mutemeri N, Sellick N, Mtegha H (2010) What is the status of small-scale mining in South Africa? Discussion document for the MQA SSM Colloquium.

8. Heemskerk M, van der Kooye R (2003) Challenges to sustainable small-scale mine development in Suriname. In Hilson G (ed.) The socioeconomic impacts of artisanal and small-scale mining in development countries. Leiden: Balkema pp: 661-678

9. Avila EC (2003) Small-scale mining: a new entrepreneurial approach. Santiago: Natural Resources and Infrastructure division.

10. South Africa Department of Water Affairs and Forestry (2006) Small-scale mining (standard format): Best practice guidelines for water resources protection in the South African mining industry. Pretoria: Government Printer.

11. Phiri S (2011) Impact of artisanal small scale gold mining in the Umzingwane
District (Zimbabwe), a potential for ecological disaster. Unpublished master's thesis, University of the Free State, Bloemfontein.

12. Van Straaten $P(2000)$ Human exposure to mercury due to small scale gold mining in northern Tanzania. The Science of the Total Environment 259: 45-53.

13. Drasch-O'Reilly G, Bose-O'Reilly S, Beinhoff C, Roider G, Maydl S (2001) The Mt Diwata study on the Philippines 1999 - assessing mercury intoxication of the population by small scale gold mining. The Science of the Total Environment 267: 151-168.

14. Mothomogolo J (2012) Development of innovative funding mechanism for mining start-up: a South African case. The South African Institute of Mining and Metallurgy.

15. Mutemeri N, Petersen FW (2002) Small-scale mining in South Africa: past, present and future. Natural Resources Forum 26: 286-292.

16. Siegel S, Veiga MM (2009) Artisanal and small-scale mining as an extra-lega economy: De Soto and the redefinition of formalisation. Resources Policy 34 51-56.

17. Barringer BR, Ireland RD (2010) Entrepreneurship: successfully launching new ventures. Upper Saddle River, New Jersey: Prentice Hall.

18. Hentschel T, Hruschka F, Priester M (2002) Global report on artisanal \& smallscale mining. London: International Institute for Environment and Development and World Business Council for Sustainable Development.

19. Hilson G (2012) Family hardships and cultural values: child labour in Malian small scale gold mining communities. The University of Reading 40: 1663 1674

20. Nieman G, Nieuwenhuizen C (2009) Entrepreneurship: a South African perspective. Van Schaik Publishers, Pretoria.

21. Evan D, Dean S (2002) Self-employment as a career choice: attitudes, entrepreneurial intentions and utility maximization. Entrepreneurial Theory and Practice 26: 81-90

22. Shane S, Kolvereid L, Westhead P (1991) An exploratory examination of the reasons leading to new firm formation across and gender. Journal of Business Venturing 6: 431-446.

23. Kirkwood J (2009) Motivational factors in a push - pull theory of entrepreneurship Gender in Management: An International Journal 24: 346-364.

24. Veiga MM, Maxson PA, Hylander LD (2006) Origin and consumption of mercury in small-scale gold mining. Journal of Cleaner Production 7: 436-447.

25. Werthman K (2009) Working in a boom-town: female perspective on goldmining in Burkina Faso. Resources Policy 34: 18-23.

26. Hilson G (2009) Small-scale mining, poverty and economic development in sub-Saharan Africa: An overview. Resources Policy 34: 1-5.

27. Sousa R, Veiga M, Van Zyl D, Telmer K, Spiegel S (2011) Policies and regulations for Brazil's artisanal gold mining sector: analysis and recommendations. Journal of Cleaner Production 19: 742-750.

28. Chamber of Mines of South Africa (2013) South African Year Book 2012/2013 Johannesburg

29. South Africa Department of Minerals Resources (2009) Mining charter impact assessment report. Pretoria: Department of Mineral Resources.

30. Glaser BG, Strauss AI (1967) The discovery of grounded theory: strategies for qualitative research. Aldine, Chicago IL.

31. Brynard PA, Hanekom SX (2006) Introduction to research in managementrelated fields. Van Schaik Publishers, Pretoria

32. Dunn DS (2010) The practical researcher: a student guide to conducting psychological research. Chichester, West Sussex: Wiley-Blackwell.

33. Gravetter FJ, Forzano LB (2009) Research methods for the behavioura sciences. Wadsworth, California: Cengage Learning.

34. Blumberg B, Cooper DR, Schindler PS (2011) Business research methods McGraw-Hill Education, Berkshire.

35. Anderson C (2010) Presenting and Evaluating Qualitative Research. American Journal of Pharmaceutical Education 74: 1-7.

36. Marshall B, Cardon P, Poddar A, Fontenot R (2013) Does sample size matter 
Citation: Mkubukeli Z, Tengeh R (2016) Prospects and Challenges for Small-Scale Mining Entrepreneurs in South Africa. J Entrepren Organiz Manag 5: 202. doi: 10.4172/2169-026X.1000202

in qualitative research? A review of qualitative interviews in research. Journal of Computer Information systems, 11-22.

37. Weerawarddena J, Mort GS (2006) Investigating social entrepreneurship: A multidimensional model. Journal of World Business 41: 21-35.

38. Bradford WD (2007) Distinguishing economically from legal formal firms: targeting business support to entrepreneurs in South Africa's townships. Journal of Small Business Management 45: 94-115.

39. Thwala WD, Phaladi MJ (2009) An exploratory study of problems facing small contractors in the North West Province of South Africa. African Journal of Business Management 3: 533-539.

40. Ladzani W, Netswera G (2009) Support for rural small businesses in Limpopo province, South Africa. Development Southern Africa 26: 225-239.

41. Cant MC, Wiid JA (2013) Establish the challenges affecting South Africa SMEs. International Business \& Economics Research Journal 12: 707-716.

42. Fatoki OO, Van Aardt Smit A (2011) Constraints to credit access by new
SMEs in South Africa: a supply-side analysis. African Journal of Business Management 5: 1413-1425.

43. Brink A, Cant M, Ligthelm A (2003) Problems experienced by small businesses in South Africa. Paper presented at the $16^{\text {th }}$ Annual conference of Small Enterprise Association of Austrialia and New Zealand, University of Ballarat, Ballarat.

44. Lekhanya LM (2010) The use of marketing strategies by small, medium and micro enterprises in rural KwaZulu-Natal. Durban University of Technology, Durban.

45. Fatoki OO (2011) The impact of human, social and financial capital on the performance of small and medium-sized enterprises in South Africa. Journal of Social Science 29: 193-204

46. Fatoki OO (2012) An investigation into the financial management practices of new micro-enterprise in South Africa. Journal of Social Science 33: 179-188.

47. Ray DE (2009) Doing research in the real world. Thousand Acres, SAGE, CA. 